Jurnal Tanah dan Sumberdaya Lahan Vol 8 No 2: 437-449, 2021

e-ISSN:2549-9793, doi: 10.21776/ub.jts1.2021.008.2.15

\title{
PENGARUH APLIKASI BAKTERI PELARUT FOSFAT DAN PUPUK ANORGANIK FOSFAT TERHADAP POPULASI BAKTERI PELARUT FOSFAT, P TERSEDIA, DAN HASIL TANAMAN JAGUNG PADA ALFISOL
}

\section{Effect of Application of Phosphate-Solubilizing Bacteria and Inorganic Phosphate Fertilizer on Population of Phosphate-Solubilizing Bacteria, Available P, and Corn Yield on an Alfisol}

\author{
Gertruda Lovitna $^{1 *}$, Yulia Nuraini ${ }^{1}$, Nurul Istiqomah ${ }^{2}$ \\ 1)Jurusan Tanah, Fakultas Pertanian, Universitas Brawijaya, Jl. Veteran No. 1, Malang 65145 \\ 2)Balai Pengkajian Teknologi Pertanian Jawa Timur (BPTP) \\ *Penulis korespondensi: glovitna97@gmail.com
}

\begin{abstract}
Fulfilment of nutrients for plants can be maximized when fertilization, but the application of inorganic fertilizers can cause damage to the soil if the dosage is excessive. The utilization of phosphate-solubilizing bacteria is an effort to increase the efficiency of phosphate fertilization that can extract phosphate from an insoluble form that becomes available. This study aimed to obtain a combination of inorganic fertilization doses (SP-36 and NPK) and the application of biological fertilizers that utilize phosphate-solubilizing bacteria (PSB) to increase the population of phosphate solubilizing bacteria and available $\mathrm{P}$ in the soil, as well as corn crop yields. This study used a randomized block design with nine treatments and three replications. The result showed that the application of PSB and inorganic phosphate fertilizer shows a significant effect on the population of PSB, available P, plant height, stover dry weight, cob weight with husk and cob weight without husk, but did not show a significant effect on 100 seeds weight and number of plant leaves. Based on the correlation analysis, the results show a positive correlation between soil chemical properties, available $\mathrm{P}$, and corn yield.
\end{abstract}

Keywords: available P, inorganic phosphate fertilizer, phosphate solubilizing bacteria

\section{Pendahuluan}

Jagung (Zea mays) merupakan komoditas strategis bagi perekonomian nasional. Kebutuhan jagung nasional dipenuhi dari produksi nasional dan impor jagung. Menurut data Kementrian Pertanian (2016) produksi jagung nasional sebesar 30,56 juta ton sedangkan impor jagung sebesar 880 ribu ton. Pada tahun 2016 luas lahan panen 5,73 juta hektar (ha) dengan produktivitas jagung sebesar $52,41 \mathrm{kw} \mathrm{ha}^{-1}$. Hal ini menandakan bahwa produksi jagung nasional belum sepenuhnya dapat memenuhi kebutuhan jagung nasional. Daerah penghasil jagung di Indonesia terbesar yaitu Provinsi Jawa Timur yang memiliki luasan panen 1,25 juta ha dengan jumlah produksi 6,3 juta ton serta produktivitas $50,4 \mathrm{kw} \mathrm{ha}^{-1}$ (BPS Jawa Timur, 2019). Tanaman jagung ditanam pada kondisi tanah yang subur salah satunya yaitu tanah berordo Alfisol.

Alfisol merupakan salah satu ordo tanah yang masih tergolong muda dan masih berkembang. Kegiatan budidaya kurang tepat dalam memanfaatkan tanah alfisol dapat memicu permasalahan. Salah satu contohnya yaitu lahan yang sering tanpa adanya pengembalian akan mengalami penurunan kesuburan baik secara kimia maupun fisik tanah. Tanah dalam kondisi tersebut sering dikenal 


\section{Jurnal Tanah dan Sumberdaya Lahan Vol 8 No 2: 437-449, 2021 e-ISSN:2549-9793, doi: 10.21776/ub.jts1.2021.008.2.15}

dengan tanah sub optimal. Kondisi tanah sub optimal seperti tanah yang masam atau basa. Tanah yang masam maka unsur fosfat $(\mathrm{P})$ akan berikatan dengan alumunium ( $\mathrm{Al}$ ) membentuk ikatan Al-P sedangkan pada tanah dengan kondisi tanah alkali unsur fosfat $(\mathrm{P})$ akan berikatan dengan kalsium (Ca) membentuk Ca$\mathrm{P}$ yang sukar larut, sehingga bentuknya tidak tersedia bagi tanaman (Ilham et al., 2014).

Hal ini menjadi salah satu permasalahan kesuburan tanah karena tidak mampu menyediakan bentuk unsur fosfat yang tersedia bagi tanaman. Unsur ini termasuk unsur yang terlibat banyak dalam tanaman salah satunya sebagai seperti pembentukan sel-sel baru tanaman, mempercepat pertumbuhan bunga dan pematangan buah, pembentukan akar, dan pembentukan biji (Akil, 2013). Namun dengan fungsinya yang sangat penting ini tidak diikuti dengan jumlah ketersediaanya sehingga diperlukan pemupukan untuk menambah jumlah dengan bentuk tersedia bagi tanaman.

Pemupukan merupakan salah satu kegiatan budidaya yang diperlukan untuk menunjang pertumbuhan tanaman namun penggunaan pupuk anorganik yang berlebihan dapat menyebabkan permasalahan pada tanah. Herdiyanto dan Setiawan (2015) menyatakan bahwa penggunaan pupuk anorganik pada petani menyebabkan penurunan bahan organik tanah, penurunan populasi mikroba tanah, permeabilitas tanah, dan beberapa dampak lain. Pemanfaatan mikroorganisme pelarut fosfat merupakan salah satu upaya untuk meningkatkan efisiensi pemupukan. Beberapa mikroorganisme (bakteri, jamur, dan aktinomisetes) pelarut fosfat yang hidup bebas di dalam tanah memiliki kemampuan dapat mengekstrak fosfat dari bentuk yang tidak larut menjadi tersedia melalui sekresi asam-asam organik sehingga tanaman dapat menyerap unsur $\mathrm{P}$ untuk mencukupi kebutuhannya (Campos et al., 2018). Hasil penelitian Sitanggang et al., (2017) menghasilkan kombinasi antara mikroorganisme pelarut fosfat dan pupuk TSP dapat meningkatkan serapan $\mathrm{P}$ sebesar 284,44\% dan meningkatkan pertumbuhan pada tanaman jagung sebesar 44,83\%. Pada penelitian Fitriatin et al., (2017) menghasilkan bahwa kombinasi dosis pupuk SP-36 dan mikroorganisme pelarut fosfat berupa bakteri pelarut fosfat berpengaruh nyata terhadap populasi bakteri pelarut fosfat dan hasil panen bobot pipilan kering jagung.

Ditinjau dari banyaknya manfaat yang dapat diberikan melalui aplikasi bakteri pelarut fosfat (BPF) dan pupuk anorganik fosfat maka penelitian ini bertujuan untuk mendapatkan kombinasi antara dosis pemupukan anorganik (SP-36 dan NPK) dan aplikasi bakteri pelarut fosfat yang terbaik untuk meningkatkan populasi bakteri pelarut fosfat dan $\mathrm{P}$ tersedia dalam tanah, serta hasil tanaman jagung.

\section{Bahan dan Metode}

\section{Tempat dan waktu penelitian}

Penelitian dilakukan pada bulan September hingga Desember 2020. Terdapat 2 pelaksanaan penelitian. Tahap pertama yaitu formulasi pupuk hayati bakteri pelarut fosfat di Laboratorium Biologi Jurusan Tanah Fakultas Petanian Universitas Brawijaya. Tahap kedua yaitu aplikasi pupuk hayati bakteri pelarut fosfat dan penanaman jagung yang dilaksanakan di lahan percobaan Balai Pengkajian Teknologi Pertanian Jawa Timur.

\section{Karakteristik Tanah}

Tanah yang digunakan dalam penelitian ini merupakan Alfisol yang berasal dari Desa Tempurrejo, Kecamatan Tempursari, Kabupaten Lumajang, Jawa Timur. Analisis dasar pada tanah digunakan sebagai acuan untuk mengetahui kondisi tanah awal sebelum diberi perlakuan. Hasil analisis dasar pada tanah yang digunakan sebagai media tanam dalam penelitian disajikan pada Tabel 1. Berdasarkan dari hasil analisis tanah dasar di atas, Alfisol di Desa Tempurrejo memiliki total populasi bakteri pelarut fosfat sebesar $14,8 \times 10^{4} \mathrm{cfu} \mathrm{g}^{-1}$, $\mathrm{pH}$ tanah sebesar 4,8 (masam), C organik sebesar 1,23\% (rendah), P total sebesar $18 \mathrm{mg}$ $100 \mathrm{~g}^{-1}$ (rendah), $\mathrm{P}$ tersedia sebesar $9 \mathrm{ppm}$ (rendah), N-total 0,04\% (sangat rendah), K-dd sebesar $0,07 \mathrm{cmol} \mathrm{kg}^{-1}$ (sangat rendah), KTK sebesar 13,48 $\mathrm{cmol} \mathrm{kg}^{-1}$ (rendah), memiliki tanah bertekstur pasir berlempung, serta memiliki kadar air sebesar 3,27\%. Tanah ini memiliki tingkat kesuburan relatif rendah dengan $\mathrm{pH}$ rendah (tingkat kemasaman yang tinggi). Nilai $\mathrm{pH}$ yang masam menyebabkan unsur hara $\mathrm{P}$ tidak tersedia bagi tanaman karena terikat oleh 


\section{Jurnal Tanah dan Sumberdaya Lahan Vol 8 No 2: 437-449, 2021 e-ISSN:2549-9793, doi: 10.21776/ub.jts1.2021.008.2.15}

unsur yang lain seperti $\mathrm{Al}$ dan Fe. Kondisi ini tentunya tidak mendukung bagi pertumbuhan tanaman jagung.

Tabel 1. Hasil analisis dasar tanah.

\begin{tabular}{|c|c|c|}
\hline Parameter & Nilai & Kriteria* \\
\hline $\begin{array}{l}\text { Total populasi } \\
\text { bakteri pelarut } \\
\text { fosfat (cfu g-1) }\end{array}$ & $14,8 \times 10^{4}$ & Rendah \\
\hline $\mathrm{pH}$ & 4,8 & Masam \\
\hline C organik (\%) & 1,23 & Rendah \\
\hline $\begin{array}{l}\text { P total } \\
\left(\mathrm{mg} 100 \mathrm{~g}^{-1}\right)\end{array}$ & 18 & Rendah \\
\hline P tersedia (ppm) & 9 & Rendah \\
\hline N-total $(\%)$ & 0,04 & $\begin{array}{l}\text { Sangat } \\
\text { rendah }\end{array}$ \\
\hline $\begin{array}{l}\text { K-dd } \\
\left(\mathrm{cmol} \mathrm{kg}^{-1}\right)\end{array}$ & 0,07 & $\begin{array}{l}\text { Sangat } \\
\text { rendah }\end{array}$ \\
\hline $\begin{array}{l}\text { KTK } \\
\left(\mathrm{cmol} \mathrm{kg}^{-1}\right)\end{array}$ & 13,48 & Rendah \\
\hline Tekstur & $\begin{array}{c}\text { Pasir } \\
\text { berlempung }\end{array}$ & - \\
\hline Kadar air (\%) & $3,27 \quad 0$ & - \\
\hline
\end{tabular}

Keterangan: *: Kriteria Berdasarkan Balittan 2009.

Menurut Ritung et al. (2011) kebutuhan unsur tanaman jagung yang tergolong $\mathrm{S} 1$ (sangat sesuai) yaitu $\mathrm{N} 0,21-0,50 \%$ (sedang), $\mathrm{P}_{2} \mathrm{O}_{5} 41-60$ mg $100 \mathrm{~g}^{-1}$ (tinggi), dan $\mathrm{K}_{2} \mathrm{O} 42-60 \mathrm{mg} 100 \mathrm{~g}^{-1}$ (tinggi). Upaya untuk meningkatkan ketersediaan P di dalam tanah dalam penelitian ini perlu dilakukan dengan pengaplikasian bakteri pelarut fosfat dan pupuk anorganik fosfat berupa pupuk SP-36 dan pupuk NPK dengan dosis $200 \mathrm{~kg} \mathrm{ha}^{-1}$. Pengaplikasian bakteri pelarut fosfat dan pupuk SP-36 serta NPK diduga dapat meningatkan ketersediaan $\mathrm{P}$ di dalam tanah yang dapat diserap oleh tanaman. Hal ini sejalan dengan penelitian Aprianto et al. (2020) bahwa penambahan pupuk anorganik fosfat dapat meningkatkan ketersediian $\mathrm{P}$ di dalam tanah serta penambahan bakteri pelarut fosfat dapat meningkatkan P tersedia di dalam tanah

\section{Pelaksanaan penelitian}

Perlakuan

Penelitian ini dilakukan dengan menggunakan rancangan acak kelompok (RAK). Penelitian ini terdiri dari 9 perlakuan dan 3 ulangan (Tabel 2).
Tabel 2. Perlakuan penelitian.

\begin{tabular}{|c|c|}
\hline Kode & Perlakuan \\
\hline P0 & Kontrol \\
\hline P1 & $100 \% \mathrm{BPF}$ \\
\hline P2 & $\begin{array}{l}100 \% \mathrm{BPF}+50 \% \text { pupuk SP-36 } \\
\left(100 \mathrm{~kg} \mathrm{ha}^{-1}\right)\end{array}$ \\
\hline P3 & $\begin{array}{l}100 \% \text { BPF }+100 \% \text { pupuk SP-36 } \\
\left(200 \mathrm{~kg} \mathrm{ha}^{-1}\right)\end{array}$ \\
\hline P4 & $\begin{array}{l}100 \% \mathrm{BPF}+150 \% \text { pupuk SP-36 } \\
\left(300 \mathrm{~kg} \mathrm{ha}^{-1}\right)\end{array}$ \\
\hline P5 & $50 \% \mathrm{BPF}$ \\
\hline P6 & $\begin{array}{l}50 \% \text { BPF }+50 \% \text { pupuk NPK }(100 \\
\left.\mathrm{kg} \mathrm{ha}^{-1}\right)\end{array}$ \\
\hline P7 & $\begin{array}{l}50 \% \mathrm{BPF}^{+} 100 \% \text { pupuk NPK } \\
\left(200 \mathrm{~kg} \mathrm{ha}^{-1}\right)\end{array}$ \\
\hline P8 & $\begin{array}{l}50 \% \mathrm{BPF}+150 \% \text { pupuk NPK } \\
\left(300 \mathrm{~kg} \mathrm{ha}^{-1}\right)\end{array}$ \\
\hline
\end{tabular}

Keterangan: BPF (Bakteri Pelarut Fosfat); Dosis $\mathrm{BPF}$ yang diberikan $50 \%=10 \mathrm{ml}$ planterbag $^{-1}$ dan $100 \%=20 \mathrm{mlplanterbag}^{-1}$.

\section{Pembuatan kultur formula pupuk bayati bakteri pelarut fosfat}

Langkah awal yang dilakukan yaitu purifikasi atau peremajaan bakteri dengan memindahkan 1 ose inokulan Pseudomonas putida koleksi Laboraturium Biologi Jurusan Tanah ke media Pikouskaya dengan cara di streak. Setelah itu ditumbuhkan selama kurang lebih 7 hari. Tumbuhnya bakteri ditandai dengan adanya lendir putih di media Pikovskaya. Bakteri yang telah ditumbuhkan selama 7 hari kemudian dihitung populasinya dan didapatkan hasil yaitu sebanyak 5,16 $\times 10^{5} \mathrm{cfu} \mathrm{ml}^{-1}$. Langkah selanjutnya yaitu memindahkan 10 ose bakteri yang tumbuh ke media Nutrient Broth (NB) 100 $\mathrm{ml}$ dan diinkubasi selama 7 hari dalam inkubator dengan suhu $30^{\circ} \mathrm{C}$ hingga larutan keruh yang menandakan banyaknya populasi BPF. Biakan bakteri tersebut dipindahkan ke media NB 900 $\mathrm{ml}$ dan diinkubasi kembali selama 7 hari.

\section{Persiapan tanam dan aplikasi bakteri pelarut fosfat}

Tanah yang digunakan sebagai media tanam yaitu Alfisol Lumajang yang akan diuji di laboratorium terlebih dahulu. Uji pendahuluan meliputi $\mathrm{pH}, \mathrm{C}$ organik, $\mathrm{P}$ total, dan $\mathrm{P}$ tersedia. Tujuan uji pendahuluan adalah untuk mengetahui kondisi awal tanah sebelum diberi perlakuan. Setelah dilakukan uji pendahuluan, 


\section{Jurnal Tanah dan Sumberdaya Lahan Vol 8 No 2: 437-449, 2021 e-ISSN:2549-9793, doi: 10.21776/ub.jts1.2021.008.2.15}

media tanam dikering anginkan lalu diayak dengan ayakan $2 \mathrm{~mm}$. Setelah itu pindahkan ke dalam planter bag berukuran 20 liter yang diisi tanah sebanyak $20 \mathrm{~kg}$. Benih jagung yang digunakan yaitu varietas Pertiwi 3. Penanaman tanaman jagung dilaksanakan di lahan percobaan Balai Pengkajian Teknologi Pertanian (BPTP) Jawa Timur. Penanaman dilakukan dengan cara membuat lubang tanam sebanyak 3 sedalam 5-7 cm lalu masing-masing lubang tanam ditanam satu benih jagung. Langkah berikutnya yaitu aplikasi kultur bakteri pelarut fosfat yang telah diinkubasi di media Nutrient Broth (NB) dengan dosis $20 \mathrm{ml}$ per planter bag (dosis 100\%) dan $10 \mathrm{ml}$ per planter bag (dosis 50\%).

\section{Pemeliharaan tanaman jagung}

Terdapat beberapa kegiatan pemeliharaan yang dilakukan yaitu pemupukan dengan pupuk SP36, NPK, $\mathrm{KCl}$, urea dan pupuk kandang sapi. Pemupukan SP-36 dan NPK diaplikasikan pada 0 HST dengan dosis rekomendasi $200 \mathrm{~kg} \mathrm{ha}^{1-}$. Pupuk urea diaplikasikan dengan dosis rekomendasi $300 \mathrm{~kg} \mathrm{ha}^{-1}$ pada 7, 28, dan $40 \mathrm{HST}$ (1 $\mathrm{g}$ planter bag ${ }^{-1}$ setiap pemupukan). Pupuk $\mathrm{KCl}$ diaplikasikan pada 7 dan 28 HST (0,25 g planter bag $^{-1}$ setiap pemupukan) dengan dosis rekomendasi $50 \mathrm{~kg}$ hat- (PTT Jagung, 2009). Pupuk kandang diaplikasikan 1 minggu sebelum tanam dengan dosis 2 ton/ha (20 g planter bag $\left.{ }^{-1}\right)$. Penyulaman yang dilakukan pada saat 7 HST. dengan cara mengganti tanaman yang mati maupun agar tanaman dapat tumbuh serentak. Penyiangan dilakukan secara manual dengan tujuan untuk membuang gulma yang tumbuh di sekitar tanaman. Tahap terakhir yaitu panen yang dilakukan setelah tanaman jagung berumur 92 HST. Ciri-ciri jagung yang telah siap dipanen yaitu daun jagung telah kering, bewarna kekuning-kuningan, dan terdapat lapisan coklat yang berada di bagian pangkal biji jagung (Firmansyah et al., 2012).

\section{Pengamatan tanaman jagung}

Pengamatan tanaman jagung dilakukan setiap satu minggu sekali $(2,3,4,5,6,7,8$ MST) dengan mengamati faktor pertumbuhan seperti tinggi tanaman dan jumlah daun. Tinggi tanaman diukur menggunakan meteran dari pangkal batang tanaman yang tumbuh di permukaan sampai pada titik tumbuh batang. Jumlah daun dihitung secara manual pada daun yang membuka sempurna.

Analisis biologi tanah

Analisis biologi tanah dilakukan untuk mengetahui populasi bakteri pelarut fosfat. Metode yang digunakan didalam perhitungan populasi bakteri tanah adalah metode pour plate. Media yang digunakan di dalam perhitungan populasi bakteri tanah adalah media Pikovskaya.

\section{Analisis kimia tanah}

Analisis kimia tanah dilakukan menggunakan 4 parameter, yaitu $\mathrm{pH}$ tanah, $\mathrm{C}$ organik, $\mathrm{P}$ total dan $\mathrm{P}$ tersedia. Analisis kimia tanah menggunakan sampel tanah komposit yang sudah dikering anginkan dan lolos ayakan $2 \mathrm{~mm}$ dan $0,5 \mathrm{~mm}$. Sampel tanah lolos ayakan $2 \mathrm{~mm}$ digunakan untuk analisis $\mathrm{pH}$ dan kadar air. Sampel tanah lolos yang ayakan $0,5 \mathrm{~mm}$ digunakan untuk analisis $\mathrm{C}$ organik, $\mathrm{P}$ total, dan $P$ tersedia.

\section{Analisis data}

Data hasil penelitian dianalisis menggunakan analisis sidik ragam atau Analysis of Variance (ANOVA) dengan uji $\mathrm{F}$ taraf $5 \%$ menggunakan aplikasi GENSTAT edisi 12 Apabila hasil yang didapatkan berpengaruh nyata maka dilakukan uji lanjut Duncan Multiple Range Test (DMRT) taraf 5\%. Selanjutnya, untuk mencari hubungan antar parameter dilakukan uji korelasi.

\section{Hasil dan Pembahasan}

\section{Populasi bakteri pelarut fosfat}

Hasil analisis ragam menunjukkan bahwa pemberian bakteri pelarut fosfat dan pupuk anorganik fosfat berpengaruh nyata terhadap populasi bakteri pelarut fosfat pada 0 MST dan panen (Tabrl 3). Pada 0 MST perbedaan nyata dapat dilihat pada nilai tertinggi yaitu pada perlakuan P8 dengan nilai sebesar 32,6 $\times 10^{4} \mathrm{cfu}$ $\mathrm{g}^{-1}$ namun tidak berbeda nyata dengan perlakuan P7. Nilai terendah yaitu pada perlakuan P0 yaitu sebesar $16,2 \times 10^{4} \mathrm{cfu} \mathrm{g}^{-1}$. Pada analisis populasi bakteri pelarut fosfat setelah panen juga menunjukkan hasil berbeda nyata dengan nilai nilai tertinggi yaitu pada perlakuan P7 dengan nilai sebesar $29,7 \times 10^{4} \mathrm{cfu} \mathrm{g}^{-1}$ namun tidak berbeda nyata pada perlakuan P8. 


\section{Jurnal Tanah dan Sumberdaya Lahan Vol 8 No 2: 437-449, 2021 e-ISSN:2549-9793, doi: 10.21776/ub.jts1.2021.008.2.15}

Tabel 1. Pengaruh pemberian bakteri pelarut fosfat dan pupuk anorganik fosfat terhadap total populasi bakteri pelarut fosfat.

\begin{tabular}{lcc}
\hline Perlakuan & Populasi bakteri pelarut fosfat $\left(\times \mathbf{1 0}^{\mathbf{4}} \mathbf{~ f u ~}_{\mathbf{~}} \mathbf{- 1}\right)$ \\
\cline { 2 - 3 } & 0 MST & Panen \\
\hline P0 (kontrol) & $16,2 \mathrm{a}$ & $12,3 \mathrm{a}$ \\
P1 (100\% BPF) & $19,6 \mathrm{ab}$ & $15 \mathrm{ab}$ \\
P2 $(100 \% \mathrm{BPF}+50 \%$ pupuk SP 36) & $18,6 \mathrm{ab}$ & $16 \mathrm{ab}$ \\
P3 (100\% BPF + 100\% pupuk SP 36) & $22,1 \mathrm{ab}$ & $19,8 \mathrm{ab}$ \\
P4 (100\% BPF + 150\% pupuk SP 36) & $22,1 \mathrm{ab}$ & $23,5 \mathrm{bc}$ \\
P5 (50\% BPF) & $24,5 \mathrm{~b}$ & $13,3 \mathrm{a}$ \\
P6 (50\% BPF + 50\% pupuk NPK) & $22,1 \mathrm{~b}$ & $19,8 \mathrm{ab}$ \\
P7 (50\% BPF + 100\% pupuk NPK) & $31,1 \mathrm{c}$ & $29,7 \mathrm{~d}$ \\
P8 (50\% BPF + 150\% pupuk NPK) & $32,6 \mathrm{c}$ & $29,1 \mathrm{~cd}$ \\
\hline Koefisien keragaman (\%) & 14,3 & 25,7 \\
\hline
\end{tabular}

Keterangan: angka yang diikuti oleh huruf yang sama pada kolom yang sama menunjukkan hasil tidak berbeda nyata menurut uji DMRT taraf 5\%.

Nilai terendah yaitu pada perlakuan P0 yaitu sebesar $12,3 \times 10^{4} \mathrm{cfu}^{-1}$ namun tidak berbeda nyata dengan P5. Populasi Bakteri Pelarut Fosfat (BPF) tertinggi terdapat di perlakuan dengan kombinasi $\mathrm{BPF} 50 \%$ dan pupuk NPK $100 \%$ rekomendasi dibandingkan dengan kombinasi BPF 100\% dan pupuk SP-36. Kecenderungan peningkatan BPF pada perlakuan dengan aplikasi pupuk NPK menunjukkan bahwa BPF mampu bekerja optimal ketika unsur P di dalam tanah sedikit. Hal ini sejalan dengan Noviani et al., (2018) yang menyatakan bahwa dalam kondisi ketersediaan hara anorganik yang berlimpah namun ketiadaan bahan organik, mikroba memperlihatkan ketidakmampuan untuk melaksanakan aktivitas metabolismenya sehingga jumlah populasi menurun. Singh dan Cowie (2014) menjelaskan bahwa keberadaan nutrisi hara anorganik menyebabkan kebutuhan tanaman menjadi segera tercukupi, sehingga bakteri tidak mendapatkan substrat yang dibutuhkan oleh sistem metabolismenya pada saat terlibat dalam proses mineralisasi unsur hara.

\section{Sifat kimia tanah}

\section{pH tanah}

$\mathrm{pH}$ merupakan derajat kemasaman yang dapat mempengaruhi ketersediaan unsur hara yang lain. Berikut merupakan hasil analisis $\mathrm{pH}$ tanah yang telah diberi perlakuan bakteri pelarut fosfat dan pupuk anorganik fosfat disajikan pada Tabel
4. Hasil analisis ragam menunjukkan bahwa pemberian pemberian bakteri pelarut fosfat dan pupuk anorganik fosfat berpengaruh nyata terhadap $\mathrm{pH}$ tanah pada 8 MST, tetapi tidak berpengaruh nyata pada 0 MST. Nilai $\mathrm{pH}$ pada 0 MST tertinggi $(6,77)$ pada perlakuan P5, dan terendah $(6,85)$ pada perlakuan P6. Pada analisis $\mathrm{pH}$ tanah 8 MST menunjukkan hasil berbeda nyata dengan nilai $\mathrm{pH}$ tertinggi yaitu pada perlakuan $\mathrm{P} 5$ dengan nilai $\mathrm{pH}$ sebesar 6,48 dan terendah pada perlakuan $\mathrm{P} 8$ dengan nilai $\mathrm{pH}$ sebesar 6,08. Bakteri akan tumbuh dengan optimal di dalam lingkungannya selama kondisinya menguntungkan bagi pertumbuhan dan untuk mempertahankan dirinya. Salah satu faktor lingkungan yang berpengaruh terhadap viabilitas suatu bakteri adalah $\mathrm{pH}$. Menurut Keneni et al. (2010), keberadaan bakteri pelarut fosfat di dalam tanah sangat dipengaruhi oleh tingkat keasaman tanah $(\mathrm{pH})$. Hasil penelitian ini menunjukkan bahwa $\mathrm{pH}$ saat akhir masa vegetatif berkisar antara 6,08-6,48 sejalan dengan hasil penelitian Noviana dan Rahardjo (2009) yang menunjukkan bahwa $\mathrm{pH}$ optimum pertumbuhan suatu bakteri terletak antara $\mathrm{pH} 6$ dan 7,5. Apabila $\mathrm{pH}$ tanah tidak optimal maka akan menganggu kerja enzim yang dihasilkan oleh bakteri dan akan mengganggu pertumbuhan bakteri. Bakteri pelarut fosfat mampu mensekresi asam organik sehingga dapat menurunkan $\mathrm{pH}$ tanah dan memecahkan ikatan pada beberapa bentuk senyawa fosfat yang tidak tersedia menjadi tersedia sehingga $\mathrm{pH}$ menjadi asam (Firdausi et al., 2016). 


\section{Jurnal Tanah dan Sumberdaya Lahan Vol 8 No 2: 437-449, 2021 e-ISSN:2549-9793, doi: 10.21776/ub.jts1.2021.008.2.15}

Tabel 2. Pengaruh pemberian bakteri pelarut fosfat dan pupuk anorganik fosfat terhadap $\mathrm{pH}$ tanah

\begin{tabular}{lcl}
\hline Perlakuan & \multicolumn{2}{c}{ Nilai pH } \\
\cline { 2 - 3 } & 0 MST & 8 MST \\
\hline P0 (kontrol) & 6,73 & $6,31 \mathrm{bcd}$ \\
P1 (100\% BPF) & 6,68 & $6,20 \mathrm{ab}$ \\
P2 (100\% BPF + 50\% pupuk SP 36) & 6,79 & $6.29 \mathrm{~b}$ \\
P3 (100\% BPF + 100\% pupuk SP 36) & 6,62 & $6.31 \mathrm{bc}$ \\
P4 (100\% BPF + 150\% pupuk SP 36) & 6,72 & $6,26 \mathrm{ab}$ \\
P5 (50\% BPF) & 6,77 & $6,48 \mathrm{c}$ \\
P6 (50\% BPF + 50\% pupuk NPK) & 6,58 & $6,16 \mathrm{ab}$ \\
P7 (50\% BPF + 100\% pupuk NPK) & 6,59 & $6,18 \mathrm{ab}$ \\
P8 (50\% BPF + 150\% pupuk NPK) & 6,62 & $6,08 \mathrm{a}$ \\
\hline Koefisien keragaman (\%) & & 1,6 \\
\hline
\end{tabular}

Keterangan: angka yang diikuti oleh huruf yang sama pada kolom yang sama menunjukkan hasil tidak berbeda nyata menurut uji DMRT taraf 5\%.

\section{C organik tanah}

Hasil analisis $\mathrm{C}$ organik tanah yang telah diberi perlakuan bakteri pelarut fosfat dan pupuk anorganik fosfat disajikan pada Tabel 5. Hasil analisis ragam menunjukkan bahwa pemberian bakteri pelarut fosfat dan pupuk anaorganik fosfat memberikan pengaruh yang nyata terhadap C organik tanah pada 8 MST, tetapi memberikan pengaruh tidak nyata pada 0 MST. Pada analisis C organik 0 MST nilai C organik tertinggi yaitu pada perlakuan P8 dengan nilai sebesar 2,42 \% dan terendah yaitu pada perlakuan P0 yaitu sebesar 1,53\%. Pada analisis C organik tanah 8 MST menunjukkan hasil berbeda nyata dengan nilai $\mathrm{C}$ organik tertinggi yaitu pada perlakuan P1 dengan nilai C organik sebesar $1,71 \%$ dan terendah pada perlakuan P5 dengan nilai C organik sebesar $0,88 \%$. Penurunan $\mathrm{C}$ organik dalam tanah dapat diduga karena bahan organik yang terkandung di dalam tanah telah mengalami dekomposisi. Bakteri pelarut fosfat dalam proses metabolismenya menggunakan bahan organik dalam tanah.

Tabel 3. Pengaruh pemberian bakteri pelarut fosfat dan pupuk anorganik fosfat terhadap $\mathrm{C}$ organik tanah.

\begin{tabular}{lcc}
\hline Perlakuan & \multicolumn{2}{c}{ C organik (\%) } \\
\cline { 2 - 3 } & 0 MST & 8 MST \\
\hline P0 (kontrol) & 1,53 & $0,98 \mathrm{a}$ \\
P1 (100\% BPF) & 1,95 & $1,71 \mathrm{e}$ \\
P2 (100\% BPF + 50\% pupuk SP 36) & 1,73 & $1,21 \mathrm{c}$ \\
P3 (100\% BPF + 100\% pupuk SP 36) & 1,67 & $1,19 \mathrm{bc}$ \\
P4 (100\% BPF + 150\% pupuk SP 36) & 1,76 & $1,02 \mathrm{ab}$ \\
P5 (50\% BPF) & 1,57 & $0,88 \mathrm{a}$ \\
P6 (50\% BPF + 50\% pupuk NPK) & 1,91 & $1,22 \mathrm{c}$ \\
P7 (50\% BPF + 100\% pupuk NPK) & 1,85 & $1,25 \mathrm{c}$ \\
P8 (50\% BPF + 150\% pupuk NPK) & 2,42 & $1,52 \mathrm{~d}$ \\
\hline Koefisien keragaman (\%) & & 8,4 \\
\hline
\end{tabular}

Keterangan: angka yang diikuti oleh huruf yang sama pada kolom yang sama menunjukkan hasil tidak berbeda nyata menurut uji DMRT taraf 5\%.

Hal ini sejalan dengan penelitian Setiawati et al. (2020) bahwa C organik merupakan sumber makanan bagi mikroorganisme yang berasal dari pupuk hayati dan dari dalam tanah sehingga $C$ organik yang berada di dalam tanah dapat berkurang keberadaannya. Chen et al. (2006) 


\section{Jurnal Tanah dan Sumberdaya Lahan Vol 8 No 2: 437-449, 2021 \\ e-ISSN:2549-9793, doi: 10.21776/ub.jts1.2021.008.2.15}

juga menyatakan bahwa aktivitas mikroorganisme pelarut fosfat dipengaruhi oleh keberadaan bahan organik yang dapat meningkatkan ketersediaan $\mathrm{P}$ dalam tanah. Keberadaan BPF dan kandungan $\mathrm{C}$ organik yang cukup tinggi akan berkontribusi terhadap pelepasan $\mathrm{P}$ tanah dari jerapan unsur lain, sehingga menambah kandungan $\mathrm{P}$ tersedia. Karbon merupakan sumber makanan bagi mikroorganisme tanah, sehingga keberadaan C organik dapat memacu aktivitas mikroorganisme serta meningkatkan proses dekomposisi tanah dan reaksi-reaksi yang memerlukan bantuan mikroorganisme, misalnya pelarut $\mathrm{P}$ dan fiksasi $\mathrm{N}$.

\section{$P$ total dan $P$ tersedia tanah}

Hasil analisis $\mathrm{P}$ total dan $\mathrm{P}$ tersedia tanah akan disajikan pada Tabel 6. Hasil analisis ragam menunjukkan bahwa pemberian bakteri pelarut fosfat dan pupuk anorganik fosfat memberikan pengaruh yang nyata terhadap P total tanah pada 0 MST dan 8 MST. Pada analisis P total tanah 0 MST perbedaan nyata dapat dilihat pada nilai tertinggi yaitu pada perlakuan P4 dengan nilai sebesar 38,28 mg $100 \mathrm{~g}^{-1}$ namun tidak berbeda nyata dengan perlakuan P8. Nilai terendah yaitu pada perlakuan P0 yaitu sebesar 26,11 mg $100 \mathrm{~g}$ ${ }^{1}$ yang tidak berbeda nyata dengan perlakuan P5. Pada analisis $\mathrm{P}$ total tanah 8 MST juga menunjukkan hasil berbeda nyata dengan nilai nilai tertinggi yaitu pada perlakuan P4 dengan nilai sebesar 42,86 mg $100 \mathrm{~g}^{-1}$ namun tidak berbeda nyata dengan perlakuan P8. Nilai terendah yaitu pada perlakuan P0 yaitu sebesar 30,84 mg $100 \mathrm{~g}^{-1}$ namun tidak berbeda nyata pada perlakuan P5. Berdasarkan Tabel 6 dapat dilihat bahwasannya terjadi peningkatan $\mathrm{P}$ total tanah pada 8 MST. Pemberian bakteri pelarut fosfat dan pupuk anorganik fosfat juga memberikan pengaruh yang nyata terhadap $\mathrm{P}$ tersedia tanah pada 0 MST dan 8 MST. Pada analisis $P$ tersedia tanah 0 MST perbedaan nyata dapat dilihat pada nilai tertinggi yaitu pada perlakuan P4 dengan nilai sebesar 21,65 ppm dan terendah yaitu pada perlakuan P0 yaitu sebesar 8,68 ppm. Pada analisis P total tanah 8 MST juga menunjukkan hasil berbeda nyata dengan nilai nilai tertinggi yaitu pada perlakuan P4 dengan nilai sebesar 29,86 ppm dan terendah yaitu pada perlakuan P0 yaitu sebesar 8,51 ppm. Kandungan $\mathrm{P}$ tersedia paling tinggi yaitu perlakuan dengan kombinasi Pemberian BPF dengan dosis 100\% (20 ml planter bag b $^{-1}$ dan $150 \%$ pupuk SP-36. Hal ini karena penambahan BPF ke dalam tanah yang tinggi dibandingkan dengan dosis 50\% (10 ml planter bag $\left.{ }^{1}\right)$. Hal ini juga diduga karena kandungan $\mathrm{P}_{2} \mathrm{O}_{5}$ dalam pupuk SP-36 lebih tinggi dibandingkan dengan kandungan $\mathrm{P}_{2} \mathrm{O}_{5}$ pada NPK. Sejalan dengan penelitian Diningtyas et al. (2018) yang menyatakan menyatakan bahwa perbedaan populasi bakteri pelarut fosfat menyebabkan perbedaan ketersediaan P di dalam tanah.

Tabel 4. Pengaruh pemberian bakteri pelarut fosfat dan pupuk anorganik fosfat terhadap P total dan P tersedia.

\begin{tabular}{|c|c|c|c|c|}
\hline \multirow[t]{2}{*}{ Perlakuan } & \multicolumn{2}{|c|}{$P$ total $\left(\mathrm{mg} 100 \mathrm{~g}^{-1}\right)$} & \multicolumn{2}{|c|}{ P tersedia (ppm) } \\
\hline & 0 MST & $8 \mathrm{MST}$ & 0 MST & $8 \mathrm{MST}$ \\
\hline P0 (kontrol) & $26,11 \mathrm{a}$ & $30,84 \mathrm{~b}$ & $8,68 \mathrm{a}$ & $8,51 \mathrm{a}$ \\
\hline P1 (100\% BPF) & 35,31 de & $37,99 \mathrm{e}$ & $10,53 \mathrm{ab}$ & $12,61 \mathrm{~b}$ \\
\hline P2 $(100 \%$ BPF $+50 \%$ pupuk SP 36$)$ & $34,52 \mathrm{~cd}$ & $35,58 \mathrm{~d}$ & $16,07 \mathrm{~d}$ & $17,67 \mathrm{~d}$ \\
\hline P3 $(100 \% \mathrm{BPF}+100 \%$ pupuk SP 36$)$ & 37,08 ef & $42,30 \mathrm{f}$ & $16,59 \mathrm{~d}$ & $25,79 \mathrm{e}$ \\
\hline $\mathrm{P} 4(100 \% \mathrm{BPF}+150 \%$ pupuk SP 36$)$ & $38,28 \mathrm{f}$ & $42,86 \mathrm{f}$ & $21,65 \mathrm{e}$ & $29,86 \mathrm{f}$ \\
\hline P5 (50\% BPF) & $26,19 \mathrm{a}$ & $28,45 \mathrm{a}$ & $16,22 \mathrm{~d}$ & $11,16 \mathrm{~b}$ \\
\hline $\mathrm{P} 6(50 \% \mathrm{BPF}+50 \%$ pupuk NPK $)$ & $30,27 \mathrm{~b}$ & $33,23 \mathrm{c}$ & $11,84 \mathrm{bc}$ & $15,73 \mathrm{c}$ \\
\hline P7 $(50 \%$ BPF $+100 \%$ pupuk NPK) & $32,96 \mathrm{c}$ & $33,31 \mathrm{c}$ & $13,25 \mathrm{c}$ & $17,38 \mathrm{~cd}$ \\
\hline $\mathrm{P} 8(50 \% \mathrm{BPF}+150 \%$ pupuk NPK $)$ & $32,79 \mathrm{c}$ & $41,66 \mathrm{f}$ & $13,58 \mathrm{c}$ & $18,94 \mathrm{~d}$ \\
\hline Koefisien keragaman (\%) & 3,5 & 3,5 & 9,6 & 5,5 \\
\hline
\end{tabular}

Keterangan: angka yang diikuti oleh huruf yang sama pada kolom yang sama menunjukkan hasil tidak berbeda nyata menurut uji DMRT taraf 5\%. 


\section{Jurnal Tanah dan Sumberdaya Lahan Vol 8 No 2: 437-449, 2021 e-ISSN:2549-9793, doi: 10.21776/ub.jts1.2021.008.2.15}

Perbedaan populasi tersebut menyebabkan perbedaan jumlah asam-asam organik yang dihasilkan oleh bakteri pelarut fosfat. Bakteri pelarut fosfat akan menghasilkan asam-asam organik. Meningkatnya asam-asam organik biasanya diikuti dengan penurunan $\mathrm{pH}$. Asam organik yang dihasilkan bakteri pelarut fosfat mampu meningkatkan ketersediaan $\mathrm{P}$ di dalam tanah (Buntan,2012).

\section{Pertumbuhan tanaman jagung}

Tinggi tanaman

Hasil analisis ragam menunjukkan hasil bahwa pemberian bakteri pelarut fosfat dan pupuk anorganik fosfat berpengaruh nyata terhadap tinggi tanaman jagung pada pengamatan 2 MST hingga 8 MST (Tabel 7). Tinggi tanaman jagung tertinggi pada awal pengamatan (2 MST) yaitu pada perlakuan P8 sebesar $8,93 \mathrm{~cm}$ dan terendah yaitu pada perlakuan P4 sebesar $6,63 \mathrm{~cm}$. Tanaman tertinggi pada akhir pengamatan $(102,36 \mathrm{~cm})$ dijumpai pada perlakuan P8, dan terendah $(81,18 \mathrm{~cm})$ pada perlakuan P0. Tanaman dengan penambahan pupuk anorganik NPK menunjukkan hasil lebih tinggi dibandingkan tanaman dengan penambahan pupuk SP-36. Tinggi tanaman berbeda nyata setiap minggunya. Hal ini disebabkan oleh sifat pupuk SP-36 yang slow release. Menurut Setyorini dan Arifin (2010), perlakuan SP-36 dengan dosis $150 \mathrm{~kg}$ SP-36 tidak menunjukkan hasil pertumbuhan yang signifikan karena sifatnya yang slow release. Pemberian SP-36 tidak langsung terlihat dalam pertumbuhan tanaman dan akan muncul pada musim tanam selanjutnya saat kondisi air dan tanah mendukung. Berbeda dengan sifat pupuk anorganik NPK yang bersifat fast release memungkinkan tanaman mendapatkan unsur makro esensisal lebih maksimal saat fase vegetatif (Laksono dan Sugiono, 2019).

\section{Jumlah daun}

Berdasarkan hasil pengamatan dan analisis ragam menunjukkan hasil bahwa pemberian bakteri pelarut fosfat dan pupuk anorganik fosfat berpengaruh nyata terhadap jumlah daun umur 2 MST namun tidak berpengaruh nyata pada umur 3 MST hingga 8 MST (Tabel 8). Pada pengamatan 2 MST jumlah daun terendah yaitu terdapat pada perlakuan P0 sebesar 3 dan tertinggi pada P5 sebesar 5, sedangkan pada pengamatan 8 MST jumlah daun terendah terdapat pada perlakuan P0 yaitu sebesar 7 dan tertinggi pada perlakuan P8 yaitu sebesar 10 . Jumlah daun tanaman jagung mengalami peningkatan setiap minggunya pada setiap perlakuan. Menurut Hartanti et al. (2014), respon pupuk terhadap jumlah daun pada umumnya kurang memberikan gambaran jelas karena pertumbuhan daun mempunyai hubungan yang erat dengan faktor genetik. Selain hal tersebut rendahnya unsur $\mathrm{N}$ yang berperan dalam pembentukan daun diduga juga menjadi salah satu penyebabnya. Lakitan (2004) menyatakan bahwa unsur hara yang paling berpengaruh terhadap pertumbuhan dan perkembangan daun adalah unsur nitrogen.

Tabel 5. Pengaruh pemberian bakteri pelarut fosfat dan pupuk anorganik fosfat terhadap tinggi tanaman jagung.

\begin{tabular}{llllllll}
\hline Perlakuan & \multicolumn{7}{c}{ Tinggi tanaman minggu ke- $\mathbf{( c m})$} \\
\cline { 2 - 8 } & \multicolumn{1}{c}{$\mathbf{2}$} & $\mathbf{3}$ & $\mathbf{4}$ & $\mathbf{5}$ & $\mathbf{6}$ & $\mathbf{7}$ & $\mathbf{8}$ \\
\hline P0 & $6,86 \mathrm{ab}$ & $9,14 \mathrm{a}$ & $14,43 \mathrm{a}$ & $18,61 \mathrm{a}$ & $35,28 \mathrm{a}$ & $52,24 \mathrm{a}$ & $81,18 \mathrm{a}$ \\
P1 & $7,62 \mathrm{bc}$ & $9,31 \mathrm{a}$ & $18,26 \mathrm{ab}$ & $21,87 \mathrm{ab}$ & $41,16 \mathrm{ab}$ & $58,32 \mathrm{bc}$ & $88,43 \mathrm{ab}$ \\
P2 & $7,38 \mathrm{abc}$ & $9,47 \mathrm{a}$ & $15,21 \mathrm{ab}$ & $20,33 \mathrm{ab}$ & $39,93 \mathrm{ab}$ & $58,53 \mathrm{bc}$ & $92,78 \mathrm{~b}$ \\
P3 & $7,78 \mathrm{c}$ & $8,56 \mathrm{a}$ & $14,82 \mathrm{ab}$ & $19,01 \mathrm{ab}$ & $36,62 \mathrm{ab}$ & $56.61 \mathrm{ab}$ & $87,29 \mathrm{ab}$ \\
P4 & $6,63 \mathrm{a}$ & $8,48 \mathrm{a}$ & $14,68 \mathrm{a}$ & $19,39 \mathrm{ab}$ & $37,03 \mathrm{ab}$ & $57,04 \mathrm{abc}$ & $88,43 \mathrm{ab}$ \\
P6 & $8,07 \mathrm{c}$ & $9,86 \mathrm{a}$ & $16,09 \mathrm{ab}$ & $21,31 \mathrm{ab}$ & $39,57 \mathrm{ab}$ & $62,09 \mathrm{~cd}$ & $91,83 \mathrm{~b}$ \\
P7 & $7,34 \mathrm{abc}$ & $9,54 \mathrm{a}$ & $18.26 \mathrm{c}$ & $23,51 \mathrm{~b}$ & $42,66 \mathrm{~b}$ & $64,78 \mathrm{~d}$ & $95,02 \mathrm{bc}$ \\
P8 & $8,93 \mathrm{~d}$ & $11,50 \mathrm{~b}$ & $21.58 \mathrm{~d}$ & $27,76 \mathrm{c}$ & $48,26 \mathrm{c}$ & $71,26 \mathrm{~d}$ & $102,36 \mathrm{c}$ \\
\hline KK $(\%)$ & 6,1 & 7,6 & 10,1 & 11,4 & 7,8 & 4,6 & 4,7 \\
\hline
\end{tabular}

Keterangan: angka yang diikuti oleh huruf yang sama pada kolom yang sama menunjukkan hasil tidak berbeda nyata menurut uji DMRT taraf 5\%. 


\section{Jurnal Tanah dan Sumberdaya Lahan Vol 8 No 2: 437-449, 2021 e-ISSN:2549-9793, doi: 10.21776/ub.jts1.2021.008.2.15}

Tabel 6. Pengaruh pemberian bakteri pelarut fosfat dan pupuk anorganik fosfat terhadap jumlah daun jagung.

\begin{tabular}{llllllll}
\hline Perlakuan & \multicolumn{7}{c}{ Jumlah daun (helai) minggu ke } \\
\cline { 2 - 9 } & $\mathbf{2}$ & $\mathbf{3}$ & $\mathbf{4}$ & $\mathbf{5}$ & $\mathbf{6}$ & $\mathbf{7}$ & $\mathbf{8}$ \\
\hline P0 & $3 \mathrm{a}$ & 4 & 5 & 7 & 8 & 8 & 9 \\
P1 & $4 \mathrm{bc}$ & 5 & 6 & 7 & 8 & 9 & 9 \\
P2 & $4 \mathrm{ab}$ & 4 & 6 & 7 & 8 & 9 & 10 \\
P3 & $4 \mathrm{~cd}$ & 5 & 6 & 7 & 8 & 9 & 10 \\
P4 & $4 \mathrm{~cd}$ & 5 & 6 & 7 & 8 & 8 & 9 \\
P5 & $5 \mathrm{~d}$ & 5 & 6 & 7 & 8 & 9 & 9 \\
P6 & $4 \mathrm{~cd}$ & 5 & 6 & 7 & 8 & 9 & 10 \\
P7 & $4 \mathrm{bcd}$ & 5 & 6 & 7 & 8 & 9 & 10 \\
P8 & $4 \mathrm{~cd}$ & 5 & 6 & 7 & 8 & 9 & 10 \\
\hline KK (\%) & 8,1 & & & & & & \\
\hline
\end{tabular}

Keterangan: angka yang diikuti oleh huruf yang sama pada kolom yang sama menunjukkan hasil tidak berbeda nyata menurut uji DMRT taraf 5\%.

\section{Hasil tanaman jagung}

Berat kering brangkasan dan bobot 100 biji

Hasil analisis ragam (ANOVA) menunjukkan hasil bahwa pemberian bakteri pelarut fosfat dan pupuk anorganik fosfat berpengaruh nyata terhadap berat kering brangkasan tanaman namun tidak berpengaruh nyata terhadap bobot 100 biji. Hasil pengamatan berat kering brangkasan tanaman jagung dan bobot 100 biji akan disajikan pada Tabel 9. Hasil tertinggi ditunjukkan pada perlakuan P7 dengan nilai 146,1 g tanaman ${ }^{-1}$ sedangkan hasil terendah ditunjukkan pada perlakuan P0 dengan nilai 91,9 g tanaman ${ }^{-1}$.

Perlakuan P7 menunjukkan berbeda nyata dengan perlakuan lainnya. Perlakuan P6, P7, dan P8 dengan kombinasi BPF dan pupuk NPK menunjukkan rerata lebih tinggi dibandingkan kombinasi BPF dan pupuk SP-36. Hal ini diduga jumlah unsur $\mathrm{P}$ yang diserap lebih optimal. Perbedaan pada berat kering brangkasan merupakan banyak sedikitnya hara yang diserap oleh tanaman, semakin besar unsur $\mathrm{P}$ yang diserap maka nilai berat kering brangkasan juga semakin tinggi.

Pernyataan ini sejalan dengan penelitian Nurlaeny dan Simarta (2014) yang menunjukkan bahwa terdapat korelasi positif antara P tersedia dengan berat kering tanaman jagung. Unsur P yang tersedia akan diserap oleh tanaman berfungsi untuk merangsang pertumbuhan akar, batang, pembungaan dan pemasakan buah.
Menurut Fahmi et al. (2009), unsur P berkolaborasi dengan unsur $\mathrm{N}$ organik dalam menunjang pertumbuhan dan perkembangan tanaman, semakin tinggi nilai berat kering brangkasan tanaman maka semakin baik tanaman tersebut dalam tumbuh dan berkembang.

Berdasarkan Tabel 9, bobot 100 biji menunjukkan bahwa semua perlakuan memberikan pengaruh yang tidak berbeda nyata dari semua perlakuan. Bobot 100 biji kering pada penelitian ini berkisar antara 11 sampai 16 g. Menurut deskripsi varietas jagung Pertiwi-3, kisaran bobot 100 biji kering 30 gram. Hasil ini menunjukkan bahwa perlakuan jenis pupuk fosfat dan aplikasi pupuk bakteri pelarut fosfat pada semua perlakuan belum dapat memberikan hasil yang optimal dalam bobot 100 biji. Hal ini sejalan dengan penelitian Wahyudin et al. (2017) yang menyatakan bahwa belum terserapnya unsur P secara optimal ke tanaman menghasilkan bobot 100 biji yang tidak nyata.

Rahni (2012) menyatakan bahwa peningkatan bobot kering biji berkaitan dengan besarnya translokasi fotosintat (hasil fotosintesis) ke dalam biji dan semakin baiknya sistem perakaran tanaman untuk mengabsorbsi unsur hara dari dalam tanah.

Bobot tongkol dengan klobot dan bobot tongkol tanpa kelobot

Berdasarkan hasil pengamatan dan analisis ragam (ANOVA) menunjukkan hasil bahwa 


\section{Jurnal Tanah dan Sumberdaya Lahan Vol 8 No 2: 437-449, 2021 e-ISSN:2549-9793, doi: 10.21776/ub.jts1.2021.008.2.15}

pemberian bakteri pelarut fosfat dan pupuk anorganik fosfat berpengaruh nyata terhadap bobot tongkol dengan klobot dan bobot tongkol tanpa klobot (Tabel 10). Hasil tertinggi berat tongkol dengan klobot ditunjukkan pada perlakuan P4 dengan nilai 297,7 $\mathrm{g}$ tongkol-1 $^{-1}$ sedangkan hasil terendah ditunjukkan pada perlakuan P0 dengan nilai $155,5 \mathrm{~g}$ tongkol ${ }^{-1}$. Perlakuan P4 menunjukkan berbeda nyata dengan perlakuan lainnya. Hasil tertinggi berat tongkol tanpa klobot ditunjukkan pada perlakuan P4 dengan nilai 288,5 $\mathrm{g}^{\text {tongkol }}{ }^{-1}$ sedangkan hasil terendah ditunjukkan pada perlakuan P0 dengan nilai $116,1 \mathrm{~g}$ tongkol-1. Perlakuan P4 yaitu pemberian 100\% BPF dan 150\% pupuk SP-36 menunjukkan hasil tertinggi dari semua perlakuan pada parameter bobot tongkol dengan klobot dan tanpa klobot. Hal ini berbanding lurus dengan ketersediaan unsur $\mathrm{P}$ yang ditunjukkan pada Tabel 7.

Tabel 7. Pengaruh pemberian bakteri pelarut fosfat dan pupuk anorganik fosfat terhadap berat kering tanaman jagung dan bobot 100 biji.

\begin{tabular}{lcc}
\hline Perlakuan & Berat kering brangkasan & Bobot 100 biji \\
\cline { 2 - 3 } & \multicolumn{2}{c}{ (g tanaman $^{-1}$ ) } \\
\hline P0 (kontrol) & $91,9 \mathrm{a}$ & 11,08 \\
P1 $(100 \% \mathrm{BPF})$ & $105,5 \mathrm{ab}$ & 13,15 \\
P2 $(100 \% \mathrm{BPF}+50 \%$ pupuk SP 36) & $111,9 \mathrm{bc}$ & 14,36 \\
P3 $(100 \% \mathrm{BPF}+100 \%$ pupuk SP 36) & $102,5 \mathrm{ab}$ & 13,38 \\
P4 (100\% BPF + 150\% pupuk SP 36) & $116,8 \mathrm{bc}$ & 13,51 \\
P5 (50\% BPF) & $92,9 \mathrm{a}$ & 14,94 \\
P6 (50\% BPF + 50\% pupuk NPK) & $121,7 \mathrm{c}$ & 14,52 \\
P7 (50\% BPF + 100\% pupuk NPK) & $146,1 \mathrm{~d}$ & 13,41 \\
P8 (50\% BPF + 150\% pupuk NPK) & $125,5 \mathrm{c}$ & 16,66 \\
\hline Koefisien keragaman $\%)$ & 7,3 \\
\hline
\end{tabular}

Keterangan: angka yang diikuti oleh huruf yang sama pada kolom yang sama menunjukkan hasil tidak berbeda nyata menurut uji DMRT taraf 5\%.

Tabel 8. Pengaruh pemberian bakteri pelarut fosfat dan pupuk anorganik fosfat terhadap bobot tongkol dengan klobot dan bobot tongkol tanpa klobot.

\begin{tabular}{lcc}
\hline Perlakuan & $\begin{array}{c}\text { Bobot tongkol } \\
\text { dengan klobot }\end{array}$ & $\begin{array}{c}\text { Bobot tongkol } \\
\text { tanpa klobot }\end{array}$ \\
\cline { 2 - 3 } & \multicolumn{2}{c}{ (g tongkol-1 $^{-1}$ ) } \\
\hline P0 (kontrol) & $155,5 \mathrm{a}$ & $116,1 \mathrm{a}$ \\
P1 (100\% BPF) & $232,4 \mathrm{c}$ & $208,6 \mathrm{~b}$ \\
P2 (100\% BPF + 50\% pupuk SP 36) & $256,9 \mathrm{e}$ & $226,0 \mathrm{c}$ \\
P3 (100\% BPF + 100\% pupuk SP 36) & $272,5 \mathrm{f}$ & $242,9 \mathrm{~d}$ \\
P4 (100\% BPF + 150\% pupuk SP 36) & $297,7 \mathrm{~g}$ & $288,5 \mathrm{f}$ \\
P5 (50\% BPF) & $223,7 \mathrm{~b}$ & $188,0 \mathrm{~b}$ \\
P6 (50\% BPF + 50\% pupuk NPK) & $243,8 \mathrm{~d}$ & $223,7 \mathrm{c}$ \\
P7 (50\% BPF + 100\% pupuk NPK) & $262,7 \mathrm{e}$ & $240,0 \mathrm{~d}$ \\
P8 (50\% BPF + 150\% pupuk NPK) & $279,7 \mathrm{~g}$ \\
\hline Koefisien keragaman (\%) & 3,3 \\
\hline
\end{tabular}

Keterangan: angka yang diikuti oleh huruf yang sama pada kolom yang sama menunjukkan hasil tidak berbeda nyata menurut uji DMRT taraf 5\%. 


\section{Jurnal Tanah dan Sumberdaya Lahan Vol 8 No 2: 437-449, 2021 e-ISSN:2549-9793, doi: 10.21776/ub.jts1.2021.008.2.15}

Kadar P pada perlakuan P4 menunjukkan hasil yang tinggi pula dibandingkan dengan perlakuan lainnya. Hal ini menunjukkan bahwa ketersediaan unsur $\mathrm{P}$ berpengaruh pada pembentukan biji dan tongkol pada tanaman jagung. Apabila tongkol tanaman terbentuk dengan sempurna maka akan memberikan berat tongkol yang tinggi. Menurut Wibowo (2017), peningkatan bobot tongkol juga berkaitan dengan besarnya fotosintat yang dialirkan ke bagian tongkol. Apabila proses transfer fotosintat ke bagian tongkol tinggi maka juga akan meningkat berat tongkol.

\section{Korelasi antara populasi bakteri pelarut fosfat, sifat kimia dan hasil tanaman jagung}

Hasil analisis korelasi menunjukkan bahwa terdapat hubungan antar parameter yang diamati pada sifat biologi tanah, kimia tanah dan pertumbuhan tanaman jagung yang disajikan pada Tabel 11. Hasil analisis korelasi menunjukkan bahwa terdapat hubungan antar parameter yang diamati pada sifat biologi tanah, kimia tanah dan pertumbuhan tanaman jagung yang disajikan pada Tabel 11. Populasi BPF menunjukkan korelasi positif dengan hubungan yang cukup kuat dengan $\mathrm{P}$ tersedia $(\mathrm{r}=0,47)$. Menunjukkan bahwa semakin tinggi populasi BPF maka akan semakin tinggi juga ketersediaan $\mathrm{P}$ di dalam tanah. Populasi BPF menunjukkan hasil korelasi yang positif dengan hubungan yang cukup kuat dengan tinggi tanaman $(r=0,52)$ yang menunjukkan bahwa semakin banyak populasi BPF maka semakin meningkat tinggi tanaman jagung. Populasi BPF menunjukkan hasil korelasi yang positif dengan hubungan yang sangat kuat dengan berat kering tanaman $(\mathrm{r}=0,80)$ yang menunjukkan bahwa semakin banyak populasi BPF maka semakin meningkat juga berat kering tanaman jagung. Nilai $\mathrm{P}$ tersedia menujukkan hasil korelasi positif dengan hubungan sangat kuat dengan bobot tongkol dengan klobot dan tanpa klobot. Nilai $\mathrm{r}$ $=0,84$ untuk bobot tongkol dengan klobot dan nilai $\mathrm{r}=0,81$ untuk bobot tongkol tanpa klobot. Korelasi ini membuktikan bahwa aktivitas BPF dapat meningkatkan keterediaan $\mathrm{P}$ di dalam tanah. Bakteri pelarut fosfat akan membantu menyediakan unsur $\mathrm{P}$ bagi tanaman dengan melarutkan $\mathrm{P}$ terjerap menjadi bentuk $\mathrm{P}$ tersedia.

Tabel 9. Korelasi antara populasi bakteri pelarut fosfat, sifat kimia tanah, dan hasil tanaman jagung.

\begin{tabular}{|c|c|c|c|c|c|c|c|c|c|}
\hline & PB & $\mathrm{pH}$ & Co & $\mathbf{P t}$ & Ptr & TT & BK & BKK & BKTK \\
\hline PB & - & & & & & & & & \\
\hline $\mathrm{pH}$ & $-0.44 * * *$ & - & & & & & & & \\
\hline Co & $0.28^{* *}$ & - & - & & & & & & \\
\hline & & $0.56^{* * *}$ & & & & & & & \\
\hline Pt & $0.39 * *$ & $-0.34 * *$ & $0.40^{* * *}$ & - & & & & & \\
\hline Ptr & $0.47 * * *$ & $-0.14^{*}$ & $-0.04^{*}$ & $0.81 * * * * *$ & - & & & & \\
\hline TT & $0.52^{* * *}$ & $-0.27 * *$ & $0.40^{* * *}$ & $0.17^{*}$ & $0,05^{*}$ & - & & & \\
\hline BK & $0.80^{* * * * *}$ & $-\overline{0.56 * * *}$ & $0.30^{* *}$ & $0.22^{* *}$ & $0,31 * *$ & $0,46^{* * *}$ & - & & \\
\hline BKK & $0,58^{* * *}$ & $-0,31 * *$ & $0,24 * *$ & $0,72 * * * *$ & $0,84 * * * * *$ & $0,50 * * *$ & $0,54 * * *$ & - & \\
\hline BKTK & $0,57 * * *$ & $-0,20 * *$ & $0,13 *$ & $0,62 * * * *$ & $0,81 * * * * *$ & 0,51 *** & $0,49 * * *$ & $0,96 * * * * *$ & - \\
\hline
\end{tabular}

Keterangan: $* * * * *=$ korelasi positif hubungan sangat kuat; $* * * *=$ korelasi positif hubungan kuat; $* * *=$ korelasi positif hubungan cukup; ${ }^{* *}=$ korelasi positif hubungan lemah; $*=$ korelasi positif hubungan sangat lemah. $\mathrm{PB}=$ populasi $\mathrm{BPF}$, $\mathrm{pH}, \mathrm{Co}=\mathrm{C}$ organik, $\mathrm{Pt}=\mathrm{P}$ total, $\mathrm{Ptr}=\mathrm{P}$ tersedia, $\mathrm{TT}=$ tinggi tanaman, $\mathrm{BK}=$ kerat kering tanaman, $\mathrm{BKK}=$ berat kering tanaman dengan klobot, BKTK = berat kering tanaman tanpa klobot.

BPF akan mengeluarkan asam-asam organik seperti asam format, asam asetat, asam propionate, asam laktat dan asam fumarat dari dalam selnya. Asam-asam organik yang dihasilkan BPF akan bereaksi dengan ion-ion $\mathrm{Ca}^{2+}, \mathrm{Fe}^{3+}$, dan $\mathrm{Al}^{3+}$ yang mengikat $\mathrm{P}$ selama ini menjadi bentuk yang tersedia bagi tanaman (Widawati dan Suliasih, 2006). Unsur P yang tersedia bagi tanaman akan diserap oleh tanaman sehingga akan memberikan hasil pada tinggi tanaman serta hasil dari berat kering tanaman. Unsur P yang tersedia bagi tanaman 


\section{Jurnal Tanah dan Sumberdaya Lahan Vol 8 No 2: 437-449, 2021 e-ISSN:2549-9793, doi: 10.21776/ub.jts1.2021.008.2.15}

yaitu dalam bentuk ion fosfat $\left(\mathrm{HPO}_{4}^{2-}, \mathrm{PO}_{4}^{3-}\right)$. Unsur $\mathrm{P}$ berperan dalam menyimpan dan mentransfer energi serta sebagai komponen protein dan asam nukleat selain itu unsur $\mathrm{P}$ yang tersedia akan diserap oleh tanaman berfungsi untuk merangsang pertumbuhan akar, pembungaan dan pemasakan buah (Marschner, 2012).

\section{Kesimpulan}

Aplikasi bakteri pelarut fosfat (BPF) dan pupuk anorganik fosfat memberikan pengaruh yang nyata terhadap populasi bakteri pelarut fosfat, $\mathrm{P}$ tersedia, dan berat kering tanaman. Terdapat korelasi positif antara populasi BPF, sifat kimia tanah, dan hasil tanaman jagung.

\section{Ucapan Terima Kasih}

Penulis mengucapkan terima kasih atas arahan dan ijin penggunaan fasilitas di lahan percobaan Balai Pengkajian Teknologi Pertanian Jawa Timur untuk pelaksanaan penelitian ini.

\section{Daftar Pustaka}

Akil,M. 2013. Kebutuhan Hara N,P, dan K Tanaman Jagung Hibridaa pada Lahan Kering di Kabupaten Gowa. Seminar Nasiobal Serealia.

Aprianto, F., Rosliani, R. dan Liferdi. 2020. Korelasi antara serapan $\mathrm{P}$ tanaman cabai (Capsicum annum L.) dengan metode penetapan $\mathrm{P}$ tersedia tanah Ordo Inceptisol Subang. Jurnal Tanah dan Sumberdaya Lahan 7(2): 321-327.

BPS Jawa Timur. 2019. Luas Panen, Produksi, dan Produktivitas Jagung dan Kedelai Menurut Kabupaten/Kota di Provinsi Jawa Timur. Diakses pada 3 Maret 2021.

Buntan, A. 2012. Efektifitas Bakteri Pelarut Fosfat dalam Kompos terhadap Peningkatan Serapan P dan Efesiensi Penyerapan $\mathrm{P}$ pada Tanaman Jagung. Program Pascasarjana IPB. Bogor.

Campos, P., Borie, F. and Cornejo, P. 2018. Phosporus acquisition effiency related to root traits: is mycorrhizal symbiosis a key factor to wheat and barley cropping?. Frontiers in Plant Science 9(3): 752-760.

Chen, Y.P., Rekha, P.D., Arunshen, A,B., Lai, W.A. and Young, C.C. 2006. Phosphate solubilizing bacteria from subtropical soil and their tricalcium phosphate solubilizing abilities. Journal of Soil Ecology 2(34): 33-41.

Diningtyas, A.S., Suarna, I.W., dan Lindawati, S.A. 2018. Evaluasi total bakteri dan bakteri pelarut fosfat pada rhizosfir tanaman Stylosanthes guianensis, Gliricidia sepium, Bracharia decumbens, dan Pennisetum purpureum di lahan kering pada musim hujan. Jurnal Pastura 8(1):54-58.

Fahmi, A., Syamsudin, Utami, S.N.H. dan Radjagukguk, B. 2009. Peran pemupukan fosfor dalam pertumbuhan tanaman jagung (Zea mays $\mathrm{L}$.) di tanah regosol dan latosol. Berita Biologi 9(6): 745-750.

Firdausi, N., Muslihatin, W. dan Nurhidayati, T. 2016. Pengaruh kombinasi media pembawa pupuk hayati bakteri pelarut fosfat terhadap $\mathrm{pH}$ dan unsur hara fosfor dalam tanah. Jurnal Sains dan Seni ITS 5(2):2337-3520.

Firmansyah, I.U., Aqil. M. dan Sinunseng, Y. 2012. Penanganan Pascapanen Jagung. Balai Penelitian Tanaman Serealia, Maros

Fitriatin, B.N., Agustina, M. dan Hindersah, R. 2017. populasi bakteri pelarut fosfat, $\mathrm{P}$ potensial, dan hasil jagung yang dipengaruhi oleh aplikasi MPF pada Ultisols Jatinangor. Jurnal Agrologia 6(2): 75-83.

Hartanti, Hapsoh, I. dan Yoseva, S. 2014. Pengaruh pemberian pupuk hayati mikoriza dan rock phosphate terhadap pertumbuhan dan produksi tanaman jagung manis (Zea Mays Saccharata Sturt). Jurnal Online Mahasiswa Fakultas Pertanian Universitas Riau 1(1): 1-14.

Herdiyanto, D. dan Setiawan, A. 2015. Upaya peningkatan kualitas tanah melalui sosialisasi pupuk hayati, pupuk organik, dan olah tanah konservasi di Desa Sukamanah dan Desa Nanggerang Kecamatan Cigalontang Kabupaten Tasikmalaya. Jurnal Aplikasi Ipteks untuk Masyarakat 4(1): 47-53.

Ilham, I.B.G., Dharmayasa, Nurjaya, I.G.M.O. dan Kawuri, R. 2014. Isolasi dan identifikasi bakteri pelarut fosfat potensial pada tanah konvensional dan tanah organik. Jurnal Simbiosis 2(1): 173183.

Keneni, A., Assefa, F. and Prabu, P.C. 2010. Isolation of phosphate solubilizing bacteria from the rhizosphere of faba bean of Ethiopia and their abilities on solubilizing insoluble phosphates. Journal of Agricultural Science and Technology 12: 79- 89.

Lakitan, B. 200. Dasar-dasar Fisiologi Tumbuban. PT Raja Grafindo Persada

Laksono, R.A. dan Sugiono, D. 2019. Optimasi pupuk NPK majemuk, pupuk daun dan POC urin sapi pada hidroponik sistem wick terhadap produksi tanaman kubis bunga (Brasicca oleracea $\mathrm{L}$. Var. Botrytis Sub.V ar. Cauliflora DC). Jurnal Ilmiah Pertanian 7(1): 24-29.

Marschner, S. 2012. Mineral Nutrition of Higher Plants. Third Edition. USA: Elsevier 


\section{Jurnal Tanah dan Sumberdaya Lahan Vol 8 No 2: 437-449, 2021 e-ISSN:2549-9793, doi: 10.21776/ub.jts1.2021.008.2.15}

Noviana, L dan Raharjo, B. 2009. Viabilitas rhizobakteri Bacillus sp. DUCC-BR-K1.3 pada media pembawa tanah gambut disubstitusi dengan padatan limbah cair industri rokok. Jurnal Bioma 11(1: 30-39.

Noviani, P.I., Slamet, S. dan Citraresmini, A. 2018. Kontribusi kompos jerami-biochar dalam peningkatan P tersedia, jumlah populasi BPF dan hasil padi sawah. Jurnal Ilmiah Aplikasi Isotop dan Radiasi 14(1): 47-57.

Nurlaeny, N. dan Simarmata, T.C. 2014. Korelasi bobot kering pupus tanaman jagung (Zea mays L.) dengan $\mathrm{Al}-\mathrm{dd}, \mathrm{Fe}$, dan $\mathrm{P}_{2} \mathrm{O}_{5}$ tersedia pada kombinasi media tanam abu vulkanik merapi, pupuk kandang sapi, dan tanah mineral. Jurnal Ilmu-Ilmu Hayati dan Fisik 16(1) :47-51.

Rahni, N.M. 2012. Efek fitohormon PGPR terhadap pertumbuhan tanaman jagung (Zea mays). Jurnal Agribisnis dan Pengembangan Wilayah 3(2) : 2735.

Ritung, S., Nugroho, K., Mulyani, A. dan E. Suryani. 2011. Petunjuk Teknis Evaluasi Lahan Untuk Komoditas Pertanian (Edisi Revisi). Balai Besar Penelitian dan Pengembangan Sumberdaya Lahan Pertanian, Badan Penelitian dan Pengembangan Pertanian, Bogor. 168 hal.

Setiawati, M.R., Suryatmana, P. dan Simarmata, T. 2020. Keragaman mikroflora, mikrofauna, kandungan $\mathrm{C}$ organik, dan total $\mathrm{N}$ tanah sawah akibat aplikasi azolla dan pupuk hayati. SoilRens 18(1): 41-49.
Setyorini, D. and Arifin, Z. 2010. Subtitution Fertilizer SP-36 by Nitro Phosphate on Shallot at Kepuharjo, Karangploso, Malang. Proceeding International Conference on Food Safety and Food Security page 72-78. Universitas Gajah Mada.

Singh, B.P. and Cowie, A.L. 2014. Long term influence of biochar on native organic carbon mineralization in low carbon clayey soil. Scientific Report 4 (3687): 1-9.

Sitanggang,V., Sembiring, M. dan Fauzi. 2017. Aplikasi mikroba pelarut fosfat dan beberapa sumber $\mathrm{P}$ untuk meningkatkan serapan $\mathrm{P}$ dan pertumbuhan tanaman jagung pada Andisol terdampak erupsi Gunung Sinabung. Jurnal Agroekoteknologi USU 5(4) : 768-773.

Wahyudin, A., Fitriatin, B.N., Wicaksono, F.Y., Ruminta, dan Rahardian, A. 2017. Respons tanaman jagung (Zea mays L.) akibat pemberian pupuk fosfat dan waktu aplikasi mikroba pelarut fosfat pada Ultisols Jatinangor. Jurnal Kultivasi 16(1) :246-254.

Wibowo, A.S. 2017. Respon hasil tanaman jagung manis (Zea mays L. Saccharata) terhadap pemberian KCL dan pupuk kotoran ayam. Jurnal Produksi Tanaman 5 (8): 1381-1388.

Widawati dan Suliasih. 2006. Augmentasi bakteri pelarut fosfat (BPF) sial sebagai pemacu pertumbuhan caysin (Brasica caventis Oed.) di tanah marginal. Jurnal Biodiversitas 7(1): 10-14. 